\title{
PENGARUH KONFLIK KERJA-KELUARGA TERHADAP KOMITMEN ORGANISASIONAL YANG DIMEDIASI OLEH KEPUASAN KERJA PADA PROFESI PERAWAT DI RUMAH SAKIT UMUM DAERAH (RSUD) DR. MOEWARDI SURAKARTA
}

\author{
Renny Rantika dan Sunjoyo \\ Fakultas Ekonomi Universitas Kristen Maranatha, Bandung
}

\begin{abstract}
The aim of this study is to examine whether work family-conflict affects the organizational commitment mediated by job satisfaction in the nursing profession. The survey is done at Rumah Sakit Umum Daerah (RSUD) Dr. Moewardi Surakarta. The subjects of this study are 152 of 154 nurses. The outliers, validity, reliability, descriptive statistic and interconstruct correlation test were conducated before hypotheses test. Path analysis was used to examine five hypotheses. The results show that two hypotheses were supported and three hypotheses were not supported. In the short, work interfering with the family negatively affects on job satisfaction and job satisfaction positively affects organizational commitment. The implications of this study were discussed and the suggested research will be advanced during the process.
\end{abstract}

Keywords: Work Family-Conflict, Job Satisfaction, Organizational Commitment.

\section{PENDAHULUAN}

Keberhasilan kerja dan kinerja individual di dalam suatu bidang pekerjaan sangatlah ditentukan oleh tingkat kompetensi, profesionalisme, komitmen organisasional dan kepuasan kerja (Setyawan, 2008). Komitmen organisasional karyawan memberikan sumbangsih yang besar baik bagi individual maupun organisasi dalam menggapai keberhasilan. Komitmen karyawan pada organisasi juga dapat dijadikan salah satu jaminan untuk menjaga kelangsungan organisasi (Indrawati, 2009). Hal ini disebabkan karena karyawan yang memiliki komitmen organisasional akan terus bertahan dan kemudian terlibat dalam upaya memperjuangkan visi, misi, serta tujuan organisasi sehingga layaklah bahwa setiap organisasi berharap untuk dapat mencapai keunggulan bersaing melalui dukungan komitmen karyawan terhadap organisasinya (Riley, 2006).

Organisasi memegang kunci yang sangat penting dalam membantu karyawan untuk membangun komitmen organisasional. Salah satunya melalui dukungan organisasi, hal ini dipertegas oleh penelitian Pack dan Soetjipto dalam Srimulyani (2009) yang menyatakan bahwa dukungan organisasi mempunyai hubungan positif dengan komitmen organisasional. Hal ini menunjukkan bahwa organisasi yang peduli dengan keberadaan dan kesejahteraan karyawannya serta menghargai kontribusi karyawan pada organisasi akan memiliki karyawan yang loyal dan dengan sukarela mengikatkan diri pada organisasi, karyawan yang tahu menyimpan rahasia perusahaan, karyawan yang akan bekerja sebaik-baiknya untuk kepentingan organisasi, senantiasa bermotivasi tinggi, bersedia berkorban bagi organisasi dan mempunyai semangat untuk maju bersama organisasi (Fauzi, 2009).

Selain dari sisi organisasi yang memberikan dukungan, penting juga untuk memperhatikan dari sisi individual sendiri. Dimana masing-masing individual juga memiliki peran untuk memiliki komitmen organisasional yang tinggi agar dapat bekerja sama dengan organisasi dan menghasilkan prestasi yang baik (Setyawan, 2008). Komitmen organisasional dapat tumbuh manakala harapan kerja dapat terpenuhi oleh organisasi dengan baik, selanjutnya dengan terpenuhi harapan kerja akan menimbulkan kepuasan kerja (Setyawan, 2008). Banyak hal yang berperan dalam mendorong terciptanya komitmen organisasional, diantaranya kepuasan-kepuasan yang diperoleh di dalam organisasi atau selama mereka bekerja. 
Selain kepuasan kerja, faktor lain yang dapat menentukan karyawan memiliki komitmen organisasional atau tidak juga dapat dipengaruhi oleh konflik kerja-keluarga. Hal ini ditunjukkan oleh penelitian Namasivayam dan Zhao (2006) yang menyatakan bahwa komitmen organisasional akan dipengaruhi oleh konflik kerja-keluarga yang mana konflik kerja-keluarga akan membawa pengaruh negatif terhadap komitmen organisasional karyawan. Konflik kerja-keluarga semakin banyak diperbincangkan mengingat meningkatnya partisipasi perempuan dalam dunia kerja. Partisipasi perempuan dalam dunia kerja meningkat dari tahun ke tahun disebabkan oleh dua faktor yaitu faktor ekonomi dan faktor non-ekonomi (Sutanto dalam Kussudyarsana \& Soepatini, 2008). Kussuyarsana dan Soepatini (2008) dalam penelitiannya menemukan bahwa konflik kerja-keluarga berpengaruh negatif terhadap kepuasan kerja sedangkan penelitian yang dilakukan Kossek dan Ozeki (1998) menemukan bahwa konflik kerja-keluarga berpengaruh negatif pula terhadap komitmen organisasional.

Penelitian ini merupakan pengembangan dari berbagai penelitian sebelumnya (Agustina, 2008; Elloy \& Smith, 2004; Namasivayam \& Zhao, 2006; Passewark \& Viator, 2006). Penelitian Agustina (2008) merupakan replikasi dari penelitian Passewark dan Viator (2008) yang menggunakan responden akuntan publik sebagai sampel dan hasilnya menunjukkan kesamaan dengan penelitian terdahulu (Passewark \& Viator, 2006). Kedua penelitian (Agustina, 2008; Passewark \& Viator, 2008) menunjukkan bahwa work interfering with the family (WIF) secara parsial berpengaruh signifikan terhadap kepuasan kerja dan family interfering with the work (FIW) memengaruhi kepuasan kerja secara tidak signifikan dengan kata lain FIW tidak berpengaruh terhadap kepuasan kerja. Sementara itu, penelitian Namasivayam dan Zhao (2006) membuktikan bahwa WIF dan FIW memengaruhi kepuasan kerja secara negatif. Berbeda dengan penelitian Elloy dan Smith (2004) yang mencoba menggali keterkaitan antara work overload, role conflict, dan role ambiguity dengan konflik kerja-keluarga dan hasilnya menunjukkan ketiga variabel tersebut memiliki hubungan signifikan dengan konflik kerja-keluarga.

Peneliti tertarik untuk melakukan pengembangan dari sejumlah penelitian sebelumnya (Agustina, 2008; Elloy \& Smith, 2004; Namasivayam \& Zhao, 2006; Passewark \& Viator, 2006) seperti yang telah dijelaskan sebelumnya. Peneliti ingin mendapatkan jawaban secara empiris mengenai bagaimana pengaruh konflik kerja-keluarga terhadap kepuasan kerja dan komitmen organisasional khususnya pada profesi perawat. Selain itu, subjek yang berprofesi perawat merupakan tenaga profesional yang keberadaannya rentan terhadap konflik kerja-keluarga.

\section{KERANGKA TEORI DAN HIPOTESIS}

\section{Komitmen Organisasional}

Menurut Mowday et al. dalam Panggabean (2006), komitmen organisasional adalah suatu keterikatan afektif dan keinginan untuk berbakti kepada sebuah organisasi. Komitmen organisasional memiliki tiga dimensi yaitu komitmen organisasional afektif, komitmen organisasional kontinuan, dan komitmen organisasional normatif. Komitmen organisasional afektif yang menurut Allen dan Mayer dalam Panggabean (2006 adalah tingkat seberapa jauh seseorang karyawan secara emosi terikat, mengenal, dan terlibat dalam organisasi. Kata-kata yang menggambarkan arti dari komitmen organisasional afektif adalah mereka ingin (want) melakukan sesuatu untuk organisasi (Allen \& Meyer 1990; Irving et al., 1997; Meyer et al., 1993). Komitmen organisasional kontinuan menurut Allen dan Mayer dalam Panggabean (2006) adalah suatu penilaian terhadap biaya yang terkait dengan meninggalkan organisasi. Kata-kata yang menggambarkan komitmen organisasional kontinuan adalah mereka perlu (need) melakukan sesuatu untuk organisasi (Allen \& Meyer 1990; Irving et al., 1997; Meyer et al., 1993). 
Komitmen organisasional normatif menurut Allen dan Mayer dalam Panggabean (2006), merupakan perasan bertanggung jawab untuk tetap tinggal dalam organisasi. Kata-kata yang menggambarkan komitmen organisasional normatif adalah ada sesuatu yang seharusnya (ought) mereka lakukan untuk organisasi (Allen \& Meyer 1990; Irving et al., 1997; Meyer et al., 1993).

\section{Kepuasan Kerja}

Locke dalam Panggabean (2006) mengemukakan bahwa kepuasan kerja merupakan pernyataan emosional positif yang dinyatakan dari hasil penilaian pekerjaan atau pengalaman kerja seseorang. Kepuasan kerja memiliki dua dimensi yaitu kepuasan kerja intrinsik dan kepuasan kerja ekstrinsik. Kepuasan kerja intrinsik dalam hal ini serupa dengan motivator factors yang menunjukkan bahwa penghargaan yang berasal dari dalam diri individual dan dirasakan pada saat melakukan pekerjaan serta tidak dapat dipisahkan dari pekerjaan itu sendiri (Christiana \& Sunjoyo, 2008). Menurut Marwansyah dan Mukaram (2000), faktor motivator adalah faktor-faktor yang terutama berhubungan langsung dengan "isi" pekerjaan (job content) atau faktor-faktor intrinsik. Faktor-faktor motivator meliputi prestasi, pengakuan, pekerjaan itu sendiri, pengembangan diri, dan tanggung jawab (Marwansyah \& Mukaram, 2000; Kossen, 1986; Fraser, 1985).

Kepuasan ekstrinsik dalam hal ini serupa dengan hygiene factors yang menunjukkan bahwa penghargaan yang berasal dari luar dan tidak menimbulkan kepuasan pada saat individual melakukan pekerjaan (Christiana \& Sunjoyo, 2008). Menurut Marwansyah dan Mukaram (2000), faktor hygiene adalah rangkaian kondisi yang berhubungan dengan lingkungan tempat pegawai yang bersangkutan melaksanakan pekerjaannya (job context) atau faktorfaktor ekstrinsik. Faktor hygiene meliputi supervisi teknis, supervisi antar-pribadi, kebijakan dan administrasi perusahaan, kondisi kerja, dan upah (Marwansyah \& Mukaram, 2000).

\section{Konflik Kerja-keluarga}

Konflik kerja-keluarga secara umum dapat didefinisikan sebagai bentuk konflik peran dimana tuntutan peran dari pekerjaan dan keluarga secara mutual tidak dapat disejajarkan dalam beberapa hal (Ching dalam Kussudyarsana \& Soepartini, 2008). Penelitian terdahulu (Agustina, 2008; Namasivayam \& Zhao, 2006; Passewark \& Viator, 2006; Riley, 2006) membagi konflik kerja-keluarga menjadi 2 (dua) dimensi yaitu:

- Work Interfering With The Family (WIF)

Menurut Kossek dan Ozeki dalam Namasivayam dan Zhao (2006), WIF merupakan konflik yang muncul ketika peran pekerjaaan mengganggu peran seseorang dalam keluarga. Contoh WIF adalah ketika seorang perempuan karir yang juga seorang ibu, merasa pekerjaannya sebagai perawat menghalanginya untuk dapat menghabiskan waktu dengan anak-anaknya seperti membantu membimbing anaknya saat mengerjakan pekerjaan rumah.

- Family Interfering With The Work (FIW)

Menurut Kossek dan Ozeki dalam Namasivayam dan Zhao (2006), FIW merupakan konflik yang muncul ketika peran seseorang dalam keluarga mengganggu peran pekerjaan. Contoh FIW adalah ketika seorang perempuan karir yang merasa pekerjaannya terganggu karena harus mengantar anaknya pergi sekolah.

\section{Hubungan Antarkonstruk Penelitian}

Hubungan antara Konflik Kerja-keluarga dan Kepuasan Kerja 
Konflik kerja-keluarga memiliki hubungan negatif dengan kepuasan kerja, hal ini dibuktikan dengan hasil penelitian yang dilakukan oleh berbagai peneliti (Anderson et al. dalam Panggabean, 2006; Bacharach dalam Agustina, 2006; Boles dalam Agustina, 2006; Frone et al. dalam Agustina, 2006; Karatepe \& Sokmen, 2006; Kossek \& Ozeki dalam Agustina, 2006; Netemeyer et al. dalam Agustina, 2006; Thomas \& Ganster dalam Agustina, 2006). Mengingat bahwa konflik kerja-keluarga memiliki 2 (dua) dimensi, yaitu Work Interfering with the Family (WIF) dan Family Interfering with the Work (FIW). Berikut ini merupakan penjelasan hubungan antara masing-masing dimensi konflik kerja-keluarga dan kepuasan kerja.

Beberapa penelitian (Anderson et al. dalam Panggabean, 2006; Bacharach dalam Agustina, 2006; Boles dalam Agustina, 2006; Kossek \& Ozeki dalam Agustina, 2006; Thomas \& Ganster dalam Agustina, 2006) menunjukkan bahwa WIF memiliki hubungan negatif dengan kepuasan kerja. Para peneliti lain (Frone et al dalam Agustina, 2006; Karatepe \& Sokmen, 2006; Netemeyer et al dalam Agustina, 2006) menemukan bahwa FIW juga memiliki hubungan negatif dengan kepuasan kerja tetapi hubungannya tidak sekuat WIF.

Kedua dimensi konflik kerja-keluarga (WIF dan FIW) memiliki hubungan negatif dengan kepuasan kerja dan penelitian Kossek dan Ozeki (1998) semakin memantapkan bahwa semua dimensi konflik kerja-keluarga mengurangi bentuk kepuasan hidup termasuk kepuasan kerja. Hubungan negatif antara konflik kerja-keluarga dan kepuasan kerja dipertegas oleh pernyataan Abbott et al. dalam Agustina (2006) bahwa konflik antara tanggung jawab pekerjaan dan keluarga mengakibatkan rendahnya kepuasaan kerja, meningkatnya absensi, menurunkan motivasi karyawan dan dalam jangka waktu tertentu dapat mengakibatkan turnover karyawan yang meningkat. Karena penelitian ini berfokus pada hubungan antara konflik kerja-keluarga, maka hipotesis yang diajukan, yaitu:

Hla: Work interfering with the family memengaruhi kepuasan kerja secara negatif. HIb: Family interfering with the work memengaruhi kepuasan kerja secara negatif.

Hubungan antara Konflik Kerja-keluarga dan Komitmen Organisasional

Beberapa penelitian (Allen \& Meyer dalam Balmforth \& Gardner, 2006; Kossek \& Ozeki dalam Balmforth \& Gardner, 2006; Netemeyer et al. dalam Balmforth \& Gardner, 2006) menunjukkan bahwa konflik kerja-keluarga memiliki hubungan negatif dengan komitmen organisasional. Hubungan negatif antara konflik kerja-keluarga dan komitmen organisasional nampak pada individual yang mengalami kesulitan dalam menyelaraskan peranannya di keluarga maupun di pekerjaan akan merasa kurang berkomitmen kepada organisasinya. Hal senada juga diungkapkan oleh Perrewe et al. dalam Namasivayam dan Zhao (2006) bahwa individual yang mengalami konflik antara pekerjaannya dan keluarganya akan mengalami "kekaburan" dan menyebabkan terjadinya penurunan komitmen organisasional pada individual tersebut. Oleh sebab itu, hipotesis yang diajukan, yaitu:

H2a: Work interfering with the family memengaruhi komitmen organisasional secara negatif. H2b: Family interfering with the work memengaruhi komitmen organisasional secara negatif.

\section{Hubungan antara Kepuasan Kerja dan Komitmen Organisasional}

Vandenberg dan Lance dalam Panggabean (2006) mengemukakan adanya hubungan timbal balik antara kepuasan kerja dan komitmen organisasional dimana kepuasan kerja memengaruhi komitmen organisasional dan kepuasan kerja dipengaruhi oleh komitmen organisasional. Hal senada juga diungkapkan oleh Mathieu dan Zajac dalam Namasivayam dan Zhao (2006) bahwa kepuasan kerja berhubungan dengan komitmen organisasional karena antara kepuasan kerja dan komitmen organisasional memiliki hubungan timbal balik.

Berdasarkan hasil penelitian Tobing (2009) menunjukkan adanya hubungan positif antara komitmen organisasional dan kepuasan kerja. Knoop dan Robert dalam Panggabean (2006) 
juga mengemukakan bahwa kepuasan kerja berpengaruh terhadap komitmen organisasional. Lebih jelasnya, komitmen organisasional memiliki hubungan positif dengan kepuasan kerja dan kualitas kerja (Mathieu \& Zajac dalam Fauzi, 2009). Oleh sebab itu, hipotesis yang diajukan dapat yaitu:

H3: Kepuasan kerja memengaruhi komitmen organisasional secara positif.

Berdasarkan 5 (lima) hipotesis yang diajukan di atas maka model penelitian dapat digambarkan sebagai berikut:

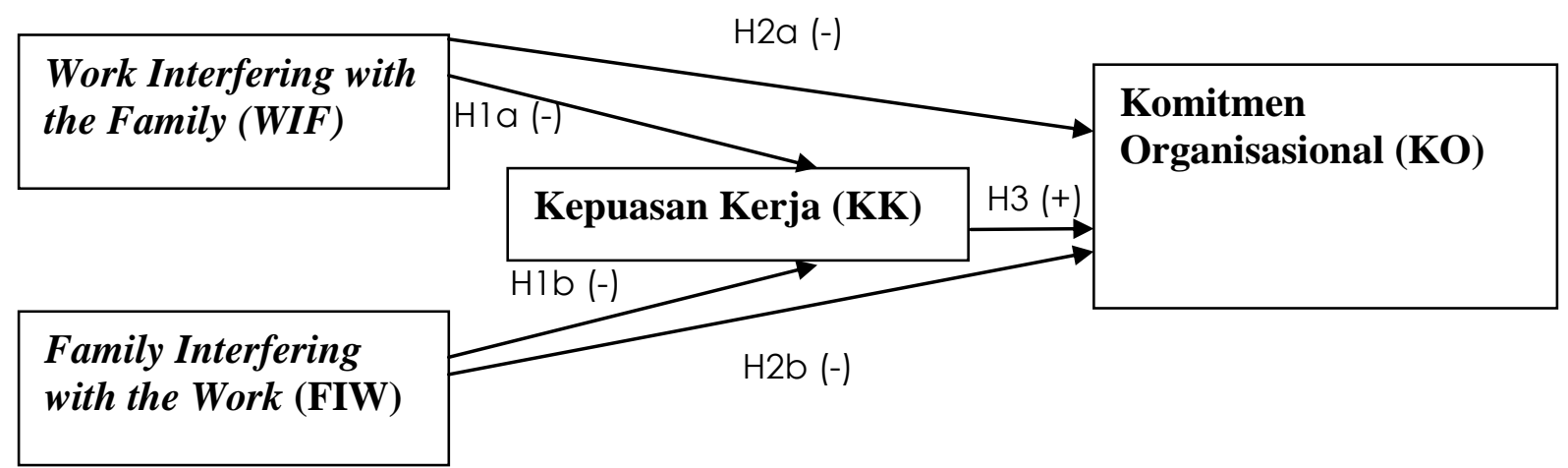

Sumber: Diadaptasi dari beberapa riset terdahulu (Agustina, 2008; Elloy \& Smith, 2004; Namasivayam dan Zhao, 2006; Passewark dan Viator, 2006).

Gambar 1

Model Penelitian yang Dihipotesiskan

\section{METODA PENELITIAN}

Subjek dan Teknik Pengumpulan Data

Subjek dari penelitian ini adalah para perawat RSUD Dr. Moewardi Surakarta. Perawat merupakan tenaga profesional yang keberadaannya rentan dengan konflik kerja-keluarga karena perawat (khususnya yang sudah kawin) memiliki dua tanggung jawab yang sama pentingnya antara bekerja dan mengurus keluarga sehingga profesi perawat dirasa sangat cocok untuk menjadi subjek dalam penelitian. Teknik pengumpulan data menggunakan metoda survei yang merupakan metode pengumpulan data primer dengan alat bantu kuesioner. Data yang berhasil dikumpulkan dari subjek para perawat sebanyak 154 dan hanya 152 data yang dapat digunakan karena dua data tidak memenuhi kriteria pengujian outliers.

Pada Tabel 1 berikut tampak karakteristik responden yang berhasil dihimpun yang disajikan secara sistematis dan rinci.

Tabel 1. Karakteristik Subjek Penelitian untuk Survei Perawat

\begin{tabular}{|l|l|l|c|}
\hline \multicolumn{1}{|c|}{ Variabel Kontrol } & \multicolumn{1}{|c|}{ Karakteristik } & Jumlah & Prosentase \\
\hline Usia & 18-24 Tahun & 10 & $6.58 \%$ \\
& 25-34 Tahun & 88 & $57.89 \%$ \\
\hline
\end{tabular}




\begin{tabular}{|l|l|l|c|}
\hline & 35-44 Tahun & 40 & $26.32 \%$ \\
& > 44 Tahun & 14 & $9.21 \%$ \\
\hline Status Perkawinan & Belum/Tidak Kawin & 15 & $9.87 \%$ \\
& Kawin & 137 & $90.13 \%$ \\
\hline Jumlah Anak & Belum/Tidak Punya Anak & 22 & $14.47 \%$ \\
& 1 Anak & 47 & $30.92 \%$ \\
& 2 Anak & 64 & $42.11 \%$ \\
& 3 Anak & 17 & $11.18 \%$ \\
& >3 Anak & 2 & $1.32 \%$ \\
\hline Lama Bekerja & < 1 Tahun & 11 & $7.24 \%$ \\
& 1-5 Tahun & 53 & $34.87 \%$ \\
& 6-10 Tahun & 37 & $24.34 \%$ \\
& 11-15 Tahun & 25 & $16.45 \%$ \\
& 16-20 Tahun & 12 & $7.89 \%$ \\
& $>$ 20 Tahun & 14 & $9.21 \%$ \\
\hline Gaji Bulanan & Rp2.000.000 & $48.03 \%$ \\
& Rp2.000.000-Rp2.999.999 & 73 & $37.50 \%$ \\
& Rp3.000.000-Rp3.999.999 & 57 & $7.89 \%$ \\
& Rp4.000.000-Rp4.999.999 & 12 & $4.61 \%$ \\
& $>$ Rp5.000.000 & 7 & $1.97 \%$ \\
\hline
\end{tabular}

Sumber: Hasil pengolahan data.

Berdasarkan karakteristik perawat yang disajikan dalam Tabel 1 di atas, maka dapat disimpulkan bahwa usia didominasi oleh responden yang berusia antara 25 dan 34 tahun $(57,89 \%)$; sebagian besar responden berstatus kawin $(90,13 \%)$; mayoritas memiliki antara 1 dan 2 anak (73,03\%) dimana responden yang memiliki 1 anak sebesar $30,92 \%$ dan yang memiliki 2 anak sebesar $42,11 \%$; didominasi oleh responden yang lama bekerjanya antara 1 dan 5 tahun (34,87\%); dan sebagian besar memiliki gaji bulanan antara kurang dari Rp2.000.000 dan Rp2.000.000-Rp2.999.999 (85,53\%) dimana responden yang mendapat gaji bulanan kurang dari Rp2.000.000 sebesar 48,03\% dan yang mendapat gaji bulanan Rp2.000.000-Rp2.999.999 sebesar 37,50\%.

\section{Pengukuran dan Operasionalisasi Variabel}

Butir instrumen dalam penelitian ini berjumlah empat puluh lima butir. Seluruh butir pernyataan tersebut diterjemahkan oleh peneliti dari bahasa Inggris ke dalam bahasa Indonesia. Selanjutnya, peneliti meminta bantuan kepada orang yang dianggap peneliti memiliki kemampuan bahasa Inggris yang baik di bidang sumber daya insani untuk merevisi setiap butir instrumen.

Konflik Kerja-keluarga. Pengukuran untuk konstruk konflik kerja-keluarga menggunakan kuesioner milik Netemeyer et al. dalam Passewark dan Viator (2006). Kuesioner konflik kerjakeluarga yang digunakan memiliki 12 (dua belas) butir pernyataan, yang terdiri atas dua dimensi konflik kerja-keluarga yaitu WIF dan FIW yang masing-masing terdiri atas 6 (enam) butir dengan rentang pilihan tanggapan dari 1 (sangat tidak setuju) hingga 5 (sangat setuju). Cronbach alpha dalam penelitian sebelumnya (Agustina, 2006; Passewark \& Viator, 2006) tidak diketahui.

Komitmen Organisasional. Pengukuran untuk komitmen organisasional mengunakan kuesioner yang dikembangkan oleh Mowday et al. dalam Ertürk et al. (2004) yang terdiri atas 15 (lima belas) butir dengan tingkat Cronbach alpha sebesar 0,93. Butir-butir pengukur komitmen organisasional yang dikembangkan oleh Mowday et al. dalam Ertürk et al. (2004) juga digunakan pada penelitian Santosa (2010) dengan koefisien Cronbach alpha sebesar 0,88 . Rentang pilihan tanggapan mulai dari 1 (sangat tidak setuju) hingga 5 (sangat setuju). 
Kepuasan Kerja. Kepuasan kerja diukur dengan kuesioner yang dikembangkan oleh Brayfield dan Rothe dalam Ertürk et al. (2004) yang terdiri atas 18 (delapan belas) butir dengan tingkat Cronbach alpha sebesar 0,92. Butir-butir pengukur kepuasan kerja yang dikembangkan oleh Brayfield dan Rothe dalam Ertürk et al. (2004) juga digunakan pada penelitian Santosa (2010) dengan koefisien Cronbach alpha sebesar 0,86. Rentang pilihan tanggapan mulai dari 1 (sangat tidak setuju) hingga 5 (sangat setuju).

\section{Prosedur Analisis Data}

\section{Uji Outliers}

Uji outliers bertujuan untuk membersihkan nilai-nilai ekstrim pada hasil observasi (sampel). Karena parameter yang digunakan dalam studi ini berjumlah tiga - konflik kerja-keluarga, kepuasan kerja dan komitmen organisasional - maka degree of freedom dapat dihitung dengan $d f=4-1=3$ sehingga $\chi^{2} d f=3, p<0,001$ adalah 16,266 maka dapat tersebut dinyatakan sebagai outliers. Tabel 2 adalah ringkasan hasil uji outliers yang dilakukan dengan bantuan program aplikasi SPSS 11.5 for windows yang hanya terdiri atas 5 (lima) data terbesar dan 5 (lima) data terkecil nilai squared mahalanobis distance.

Tabel 2. Hasil Uji Outliers - Squared Mahalanobis Distance

\begin{tabular}{|c|c|c|}
\hline Data/Kasus & $\begin{array}{c}\text { Nilai Squared Mahalanobis } \\
\text { Distance }\end{array}$ & $\begin{array}{c}\text { Nilai Squared Mahalanobis Distance yang } \\
\text { diharapkan }\end{array}$ \\
\hline 132 & 18.56619 & \\
74 & 16.38448 & \\
45 & 10.52336 & \\
6 & 10.35915 & \\
8 & 10.35915 & Squared Mahalanobis Distance < 16,266 \\
. & $\cdot$ & \\
. &. & \\
62 &. & \\
108 & 0.11013 & \\
110 & 0.07842 & \\
111 & 0.07842 & \\
118 & 0.07842 & \\
\hline
\end{tabular}

Sumber: Hasil Pengolahan Data

Keterangan: Data/Kasus yang dicetak miring adalah data outliers

Berdasarkan hasil pengujian tersebut ditemukan bahwa terdapat 2 dari 154 data survei perawat tidak lolos uji outliers. Dengan demikian, data yang dapat digunakan untuk analisis lebih lanjut adalah 152 data.

\section{Uji Validitas}

Nilai absoulut analisis faktor untuk setiap dimensi/butir instrumen dikatakan valid apabila setiap dimensi/butir instrumen bernilai factor loadings di atas $|0,3|$ (rules of thumbs) (Hair et al., 1998). Tabel 3 berikut adalah ringkasan hasil analisis faktor konfirmatori atau confirmatory factor analysis (CFA) yang dilakukan dengan bantuan program SPSS 11.5 for windows terhadap konstruk konflik kerja-keluarga, kepuasan kerja dan komitmen organisasional.

Tabel 3. Hasil Analisis Faktor untuk Setiap Konstruk dan Butir Instrumen Penelitian

\begin{tabular}{|l|l|l|l|l|l|}
\hline \multirow{2}{*}{ Konstruk } & \multirow{2}{*}{ Butir } & \multicolumn{4}{|c|}{ Factors Loading } \\
\cline { 3 - 6 } & & 1 & 2 & 3 & 4 \\
\hline
\end{tabular}




\begin{tabular}{|c|c|c|c|c|c|}
\hline WIF & $\begin{array}{l}\text { WIF1 } \\
\text { WIF2 } \\
\text { WIF3 } \\
\text { WIF4 } \\
\text { WIF6 }\end{array}$ & $\begin{array}{l}0,733 \\
0,814 \\
0,806 \\
0,735 \\
0,697\end{array}$ & & & \\
\hline FIW & $\begin{array}{l}\text { FIW1 } \\
\text { FIW2 } \\
\text { FIW3 } \\
\text { FIW4 } \\
\text { FIW5 } \\
\text { FIW6 }\end{array}$ & & $\begin{array}{l}0,632 \\
0,833 \\
0,774 \\
0,753 \\
0,732 \\
0,711\end{array}$ & & \\
\hline$O C$ & $\begin{array}{l}\text { OC2 } \\
\text { OC4 } \\
\text { OC5 } \\
\text { OC6 } \\
\text { OC } 8 \\
\text { OC } 10 \\
\text { OC } 13 \\
\text { OC } 14\end{array}$ & & & $\begin{array}{l}0,691 \\
0,387 \\
0,557 \\
0,712 \\
0,654 \\
0,771 \\
0,676 \\
0,733\end{array}$ & \\
\hline JS & $\begin{array}{l}\text { JS1 } \\
\text { JS2 } \\
\text { JS5 } \\
\text { JS7 } \\
\text { JS9 } \\
\text { JS12 } \\
\text { JS13 } \\
\text { JS15 } \\
\text { JS } 17\end{array}$ & & & & $\begin{array}{l}0,484 \\
0,543 \\
0,516 \\
0,694 \\
0,561 \\
0,737 \\
0,555 \\
0,527 \\
0,408\end{array}$ \\
\hline
\end{tabular}

Sumber: Hasil pengelolahan data

Keterangan:

WIF = Work Interfering with the Family; FIW = Family Interfering with the Work; JS = Job Satisfaction; $O C=$ Organizational Commitment.

Berdasarkan hasil analisis data pada Tabel 3 di atas, maka dapat disimpulkan bahwa 28 dari 45 butir instrumen dinyatakan lolos uji validitas. Dengan demikian, butir-butir instrumen yang tidak lolos uji validitas (WIF5, CO1, CO3, CO7, CO9, CO11, CO12, CO15, JS3, JS4, JS6, JS8, JS10, JS11, JS14, JS16, JS18) akan dieliminasi dan tidak akan digunakan dalam berbagai analisis selanjutnya.

\section{Uji Reliabilitas}

Pengujian uji reliabilitas menggunakan koefisien Cronbach's alpha (a). Hasil pengujian reliabilitas menunjukkan bahwa 28 dari 45 butir instrumen riset memenuhi kriteria Cronbach's alpha $\geq 0,6$. Menurut Sekaran (2000) menyatakan bahwa koefisien Cronbach's alpha yang kurang dari 0,6 adalah buruk, antara 0,6 dan 0,8 dapat diterima, dan di atas 0,8 adalah baik. Tabel 4 di bawah ini, menunjukkan hasil uji reliabilitas untuk setiap konstruk penelitian dengan bantuan program SPSS 11.5 for windows.

Tabel 4. Hasil Uji Reliabilitas untuk Setiap Konstruk

\begin{tabular}{|c|c|}
\hline Konstruk* $^{*}$ & Koefisien Cronbach's alpha \\
\hline WIF & 0,818 \\
\hline
\end{tabular}




\begin{tabular}{|c|c|}
\hline FIW & 0,844 \\
\hline OC & 0,808 \\
\hline JS & 0,729 \\
\hline
\end{tabular}

Sumber: Hasil Pengolahan Data

Keterangan:

"WIF = Work Interfering with the Family; FIW = Family Interfering with the Work; JS = Job Satisfaction; $O C=$ Organizational Commitment.

\section{Uji Statistik Deskriptif dan Korelasi Antarkonstruk Penelitian}

Pengujian korelasi konstruk bertujuan untuk mengetahui seberapa kuat hubungan antarkonstruk penelitian ini. Selain itu, penelitian ini juga menampilkan hasil uji statistik deskriptif dengan mean dan deviasi standar untuk mengetahui kecenderungan responden (sampel) terhadap setiap konstruk penelitian ini dan untuk menilai rata-rata dispersi responden. Ketiga pengujian tersebut (korelasi, mean, dan deviasi standar) dilakukan dengan menggunakan program aplikasi SPSS 11.5 for Windows. Tabel 5 berikut merupakan hasil pengujian statistik deskriptif dan korelasi data penelitian ini.

Tabel 5. Hasil Uji Statistik Deskriptif dan Korelasi Antarkonstruk Penelitian

\begin{tabular}{|l|c|c|c|c|c|c|c|c|c|c|}
\hline \multicolumn{1}{|c|}{ Var } & $M$ & $S D$ & 1 & 2 & 3 & 4 & 5 & 6 & 7 & 8 \\
\hline 1. US & 2,38 & 0,743 & & & & & & & & \\
\hline 2. SP & 1,91 & 0,310 & $0,351^{* *}$ & & & & & & & \\
\hline 3. JA & 2,54 & 0,916 & $0,521^{* *}$ & $0,542^{* *}$ & & & & & & \\
\hline 4. LB & 3,09 & 1,393 & $0,807^{* *}$ & $0,307^{* *}$ & $0,503^{* *}$ & & & & & \\
\hline 5. GB & 1,74 & 0,927 & $0,373^{* *}$ & $0,167^{*}$ & $0,358^{* *}$ & $0,565^{* *}$ & & & & \\
\hline 6. WIF & 2,0987 & 0,64686 & 0,040 & $-0,040$ & $-0,057$ & $-0,046$ & $-0,033$ & & & \\
\hline 7. FIW & 2,0736 & 0,57986 & 0,093 & $-0,029$ & $-0,069$ & 0,004 & $-0,035$ & $0,615^{* *}$ & & \\
\hline 8. JS & 3,6407 & 0,45036 & 0,002 & $-0,116$ & $-0,022$ & 0,100 & 0,013 & 0,098 & 0,041 & \\
\hline 9. OC & 3,7476 & 0,52520 & 0,092 & $-0,052$ & 0,101 & $0,175^{*}$ & 0,101 & $0,175^{* *}$ & 0,073 & $0,661^{* *}$ \\
\hline
\end{tabular}

Sumber: Hasil Pengolahan Data

Keterangan:

${ }^{* *} p<0,01$ (dua-sisi); ${ }^{*} p<0,05$ (dua sisi); SD = Standard Deviation; US = Usia $(1=18-24$ tahun; $2=$ 25-34 tahun; $3=35-44$ tahun; $4=>44$ tahun); $S P$ = Status Perkawinan ( 1 = Belum/Tidak kawin; 2 = Kawin); JA = Jumlah Anak ( 1 = Belum/Tidak punya anak; $2=1$ anak; $3=2$ anak; $4=3$ anak; $5=>3$ anak); $L B=$ Lama Bekerja $(1=<1$ tahun; $2=1-5$ tahun; $3=6-10$ tahun; $4=11-15$ tahun; $5=16-20$ tahun; $6=>20$ tahun); $G B=$ Gaji Bulanan $(1=<$ Rp2.000.000; $2=$ Rp2.000.000-Rp2.999.999; $3=$ Rp3.000.000-Rp3.999.999; $4=R p 4.000 .000-R p 4.999 .999 ; 5=>$ Rp5.000.000); WIF = Work Interfering with the Family; FIW = Family Interfering with the Work; JS = Job Satisfaction; OC = Organizational Commitment; Var = Variabel.

Berdasarkan Tabel 5, nilai mean pada konstruk WIF dan FIW menunjukkan tingkat relatif rendah $-2,0736$ dan 2,0987 dan nilai deviasi standar (dispersi) juga relatif rendah $-0,57986$ dan 0,64686 . Nilai mean pada konstruk komitmen organisasional menunjukkan bahwa tingkat komitmen organisasional para perawat relatif tinggi - 3,7476 dan nilai deviasi standar (dispersi) yang relatif rendah $-0,52520$. Sedangkan nilai mean pada konstruk kepuasan kerja menunjukkan standar relatif tinggi - 3,6407 dan nilai deviasi standar (dispersi) yang relatif rendah $-0,45036$.

Tabel 5 juga menyajikan korelasi antarkonstruk penelitian yang signifikan ditemukan, yaitu: antara WIF dan FIW $(r=0,615 ; p<0,01)$, nilai koefisien korelasi 0,615 ini menunjukkan hubungan korelasi yang cukup berarti. Apabila WIF meningkat, maka FIW juga akan meningkat. Demikian sebaliknya, apabila WIF menurun maka FIW juga akan menurun. Korelasi antarkonstruk penelitian lain yang signifikan adalah antara WIF dan komitmen 
organisasional $(r=0,175 ; p<0,01)$, nilai koefisien korelasi 0,175 ini menunjukkan hubungan korelasi yang sangat lemah. Apabila WIF meningkat maka komitmen organisasional juga akan meningkat. Demikian sebaliknya, apabila WIF menurun maka komitmen organisasional juga akan menurun. Penemuan ini menujukkan hal yang bertentangan dengan teori, karena berdasarkan teori terdapat hubungan negatif antara WIF dan kepuasan kerja.

Korelasi antarkonstruk penelitian lain yang signifikan adalah antara kepuasan kerja dan komitmen organisasional $(r=0,661 ; p<0,01)$, nilai koefisien korelasi 0,661 ini menunjukkan hubungan korelasi yang cukup berarti. Apabila kepuasan kerja meningkat maka komitmen organisasional juga akan meningkat. Demikian sebaliknya, apabila kepuasan kerja menurun maka komitmen organisasional juga akan menurun. Melihat adanya korelasi yang cukup berarti antara kepuasan kerja dan komitmen organisasional, maka pihak manajemen RSUD Dr. Moewardi Surakarta perlu memperhatikan kepuasan kerja perawat agar komitmen organisasional perawatpun dapat meningkat. Tabel 5 juga menunjukkan korelasi yang signifikan yang ditemukan antara lama bekerja dan komitmen organisasional $(r=0,175 ; p<$ $0,05)$, nilai koefisien 0,175 ini menunjukkan hubungan korelasi yang sangat lemah. Hal ini menunjukkan apabila semakin lama perawat bekerja maka perawat tersebut dapat memiliki komitmen organisasional yang semakin tinggi namun perlu diperhatikan bahwa pengaruhnya sangat lemah.

\section{Uji Fit Model Pengukuran}

James et al. (1982) menjelaskan bahwa pola "confirmatory" menunjukkan prosedur-prosedur dirancang untuk mengevaluasi utilitas hipotesis-hipotesis dengan pengujian fit antara model teoritis dan data empiris. Jika model teoritis menggambarkan "good fit" dengan data, maka model dianggap sebagai yang diperkuat. Sebaliknya, suatu model teoritis tidak diperkuat jika teori tersebut mempunyai suatu "poor fit" dengan data. Tabel 6 berikut menunjukkan hasil uji "fit" model. Secara umum, model dinyatakan "marginal fit". Besar kemungkinan hasil goodness of fit measures ini adalah disebabkan karena sample size kurang memenuhi syarat yaitu sebaiknya berkisar antara 200-500 jika menggunakan alat analisis SEM (Hair et al., 1998).

Tabel 6. Goodness of Fit Measures

\begin{tabular}{|l|c|c|c|}
\hline Goodness of Fit Index & $\begin{array}{c}\text { Syarat yang harus } \\
\text { Dipenuhi* }\end{array}$ & Hasil Perhitungan & Keterangan \\
\hline $\begin{array}{l}\text { Degree of freedom } \\
\text { (df) }\end{array}$ & Positif & 344 & Baik \\
\hline Probability & $>0,20$ & 0,000 & Marginal \\
\hline$\chi^{2}$ statistic & $\geq 0,05$ & 955,591 & Marginal \\
\hline RMSEA & $\leq 0,08$ & 0,109 & Marginal \\
\hline GFI & $\geq 0,90$ & 0,689 & Marginal \\
\hline CMIN/DF & $\leq 0,30$ & 2,778 & Marginal \\
\hline TLI & $\geq 0,95$ & 0,629 & Marginal \\
\hline CFI & $\geq 0,95$ & 0,663 & \\
\hline
\end{tabular}

Sumber: Hasil pengolahan data

Keterangan:

RMSEA=The Root Mean Square Error of Approximation; GFI=Goodness of Fit Index (GFI); CMIN/DF=The Minimum Sample Discrepancy Function/degree of freedom; TLI=Tucker Lewis Index; CFI=Comparative Fit Index.

* Berdasarkan Ferdinand (2002: 61).

\section{Uji Hipotesis}

SEM dengan bantuan program aplikasi AMOS digunakan untuk menganalisis hubungan di antara variabel-variabel laten. SEM juga dapat mengestimasi nilai-nilai path dari setiap hubungan variabel (Turban \& Dougherty, 1994). Dengan menggunakan analisis SEM maka 
semua hipotesis dalam studi ini dapat diuji dengan path analysis. Setiap hipotesis dapat diuji dengan membandingkan nilai critical ratio $(C R)$ dan nilai t-tabel pada degree of freedom (df) tertentu. Apabila nilai $C R$ lebih besar daripada nilai t-tabel pada $d f$ tertentu maka hubungan konstruk yang diuji dapat dinyatakan signifikan pada level probabilitas tertentu yaitu < 0,05 (Sunjoyo, 2008). Namun dalam batasan ilmu sosial masih mentolerir hipotesis yang signifikan pada tingkat 0,10 (Kerlinger, 1993). Menurut Ferdinand (2002) aturan umum yang biasa digunakan adalah apabila $C R \geq|2,0|$ maka hipotesis didukung atau tidak ditolak. Tabel 7 berikut ini merupakan hasil uji hipotesis.

Tabel 7. Hasil Pengujian Hipotesis

\begin{tabular}{|c|c|c|c|}
\hline Hipotesis & Hubungan Struktural & Critical Ratio $(C R)$ & Keterangan \\
\hline Hipotesis la & JS $\leftarrow$ WIF & $-1,665^{*}$ & Hla didukung \\
\hline Hipotesis $1 \mathrm{~b}$ & $\mathrm{JS} \leftarrow \mathrm{FIW}$ & 1,116 & H1b tidak didukung \\
\hline Hipotesis $2 \mathrm{a}$ & $\mathrm{OC} \leftarrow \mathrm{WIF}$ & $-0,108$ & H2a tidak didukung \\
\hline Hipotesis $2 \mathrm{~b}$ & $\mathrm{OC} \leftarrow \mathrm{FIW}$ & $-0,995$ & H2b tidak didukung \\
\hline Hipotesis 3 & $\mathrm{OC} \leftarrow \mathrm{JS}$ & $3,490^{* *}$ & H3 didukung \\
\hline
\end{tabular}

Sumber: Hasil pengolahan data

Keterangan:

${ }^{*} \mathrm{p}<0,10 ;{ }^{* *} \mathrm{p}<0,05$; WIF = Work Interfering with the Family; FIW = Family Interfering with the Work; JS = Job Satisfaction; OC = Organizational Commitment.

Tabel 7 di atas menunjukkan bahwa Hipotesis la tidak didukung pada $p<0,5$. Apabila menggunakan acuan $\mathrm{p}<0,10$ (Kerlinger, 2002), maka Hipotesis la didukung. Artinya, WIF memengaruhi kepuasan kerja secara negatif sehingga temuan ini mengkonfirmasi beberapa penelitian terdahulu (Anderson et al. dalam Panggabean, 2006; Bacharach dalam Agustina, 2006; Boles dalam Agustina, 2006; Frone et al. dalam Agustina, 2006; Karatepe \& Sokmen, 2006; Kossek \& Ozeki dalam Agustina, 2006; Netemeyer et al. dalam Agustina, 2006; Thomas \& Ganster dalam Agustina, 2006).

Tabel 7 menunjukkan bahwa Hipotesislb tidak didukung. Hal ini menunjukkan bahwa FIW tidak memengaruhi kepuasan kerja sehingga dalam hal ini temuan ini tidak mengkonfirmasi beberapa penelitian terdahulu (Anderson et al. dalam Panggabean, 2006; Bacharach dalam Agustina, 2006; Boles dalam Agustina, 2006; Frone et al. dalam Agustina, 2006; Karatepe \& Sokmen dalam Agustina, 2006; Kossek \& Ozeki dalam Agustina, 2006; Netemeyer et al. dalam Agustina, 2006; Thomas \& Ganster dalam Agustina, 2006) yang menemukan adanya pengaruh FIW terhadap kepuasan kerja.

Tabel 7 juga menunjukkan bahwa Hipotesis $2 a$ dan Hipotesis $2 b$ tidak didukung. Hal ini menunjukkan baik WIF maupun FIW tidak memengaruhi komitmen organisasional. Temuan ini tidak mengkonfirmasi beberapa penelitian terdahulu (Allen \& Meyer dalam Balmforth \& Gardner, 2006; Kossek \& Ozeki dalam Balmforth \& Gardner, 2006; Netemeyer et al. dalam Balmforth \& Gardner, 2006).

Tabel 7 juga menunjukkan bahwa, Hipotesis 3 didukung. Hal ini menunjukkan bahwa kepuasan kerja memengaruhi komitmen organisasional secara positif. Temuan ini mengkonfirmasi beberapa penelitian terdahulu (Knoop \& Robert dalam Panggabean, 2006; Mathieu \& Zajac dalam Fauzi, 2009; Tobing, 2008) yang menemukan adanya pengaruh postif antara kepuasan kerja terhadap komitmen organisasional.

\section{SIMPULAN}

Studi ini merupakan pengembangan dari beberapa studi yang telah dilakukan oleh peneliti sebelumnya (Agustina, 2008; Elloy \& Smith, 2004; Namasivayam \& Zhao, 2006; Passewark \& Viator, 2006) mengenai konflik kerja-keluarga yang bertujuan untuk menguji pengaruh konflik 
kerja-keluarga terhadap komitmen organisasional yang dimediasi oleh kepuasan kerja pada profesi perawat di RSUD Dr. Moewardi Surakarta. Dua dari lima hipotesis didukung. Hasil temuan menunjukkan bahwa WIF memengaruhi kepuasan kerja secara negatif $(\gamma=-0,324, p$ $<0,10)$. Hasil temuan juga menemukan bahwa kepuasan kerja memengaruhi komitmen organisasional secara positif $(\gamma=0,839 ; p<0,05)$. Studi ini tidak menemukan adanya pengaruh negatif antara FIW dan kepuasan kerja (Hipotesis 1b). Studi ini juga tidak menemukan adanya pengaruh negatif antara WIF dan komitmen organisasional (Hipotesis 2a) serta tidak ada pengaruh negatif antara FIW dan komitmen organisasional (Hipotesis 2b).

\section{KETERBATASAN DAN SARAN BAGI PENELITIAN MENDATANG}

Terdapat beberapa keterbatasan penelitian ini. Pertama, subjek penelitian ini tidak memenuhi jumlah responden minimum (data yang terkumpul hanya 154 data sedangkan jumlah minimum untuk populasi sebanyak 269 orang berdasarkan rumus Slovin yaitu 160 data). Kedua, pengumpulan data hanya mengandalkan kuesioner yang diisi oleh para responden. Dalam hal ini penulis hanya mengandalkan jawaban dari kuesioner saja karena penulis tidak melakukan wawancara dan tidak mengamati secara langsung. Ketiga, objek dan subjek penelitian ini hanya RSUD Dr. Moewardi Surakarta. Keempat, pengujian goodness of fit model kurang memenuhi "good fit" karena indikator-indikator yang dihasilkan sebagian besar hanya mencapai "marginal fit".

Untuk penelitian mendatang, beberapa saran perlu dipertimbangkan oleh para peneliti di masa mendatang. Pertama, memenuhi syarat sampel minimum antara 200 dan 500 data dalam menggunakan SEM sebagai alat analisitik statistik (Hair et al., 1998). Kedua, dalam pengumpulan data dapat pula ditambah dengan wawancara atau observasi langsung kepada subjek penelitian. Ketiga, objek dan subjek penelitian dapat dilakukan lebih luas yaitu antar lintas profesi dan industri sehingga hasil studi lebih dapat digeneralisasikan. Keempat, pengujian goodness of fit harus memenuhi "good fit". Terakhir, menambah konstruk-konstruk baru yang berkaitan dan mendukung pengaruh konflik kerja-keluarga. Konstruk yang dapat menjadi anteseden dari konflik kerja-keluarga yaitu work overload (Elloy \& Smith, 2004), role conflict (Elloy \& Smith, 2004), role ambiguity (Elloy \& Smith, 2004), locus of control (Noor, 2006). Konstruk yang dapat menjadi outcomes dari konflik kerjakeluarga yaitu turnover intention (Agustina, 2008), turnover (Triaryati, 2003), organizational citizhen behavior (Balmforth \& Gardner, 2006), absenteeism (Triaryati, 2003), motivasi (Triaryati, 2003), keterlibatan kerja (Panggabean, 2006).

\section{DAFTAR PUSTAKA}

Allen, N.J. \& Meyer, J.P. (1990). The measurement and antecedents of affective, continuance and normative to the organization. Journal of Occupational Psychology, 63, 1-18.

Agustina, L. (2008). Pengaruh work-family conflict terhadap job satisfaction dan turnover intention pada profesi akuntan publik: Studi empiris pada kantor akuntan publik di DKI Jakarta dan Bandung. Jurnal IImiah Akuntansi, 7 (2), 100-116.

Balmforth, K. \& Gardner, D. (2006). Conflict and facilitation between work and family: Realizing the outcomes for organizations. New Zealand Journal of Psychology, 35 (2), 69-76.

Christiana, M. \& Sunjoyo (2008). Pengaruh kepuasan kerja terhadap komitmen organisasional yang dimediasi oleh identifikasi organisasional. Jurnal Manajemen, 7 (2), 157-176.

Elloy, D. F. \& Smith, C. (2004). Antesedents of work-family conflict among dual-career couples: An Australian study. Cross Cultural Management, 11 (4), 17-27. 
Ertürk, A., Yilmaz, C., \& Ceylan, A. (2004). Promoting organizational citizenship behaviour: Relative effects of job satisfaction, organizational commitment, and perceived managerial fairness. METU Studies in Development, 189-210.

Fauzi, S. N. (2009). Pengaruh komitmen organisasi terhadap kepuasan kerja dengan motivasi sebagai variabel moderating: Survey di kantor akuntan publik di karisidenan Surakarta dan Yogyakarta. Skripsi yang tidak dipublikasikan, Universitas Muhamadiyah, Surakarta.

Ferdinand, A. (2002). Structural equation modeling dalam penelitian manajemen: Aplikasi model-Mmdel rumit dalam penelitian untuk tesis magister dan disertasi doktor. Semarang: BP Universitas Diponegoro.

Fraser, T.M. (1985). Stres dan kepuasan kerja, Jakarta: PT Pustaka Binaman Pressindo.

Hair, Jr., J.F., Anderson, R.E., Tatham, R.L., \& Black, W.C. (1998). Multivariate data analysis. $5^{\text {th }}$ edition, NJ: Pretice-Hall International, Inc.

Indrawati, E. (2009). Pengaruh komitmen organisasional dan kepuasan kerja terhadap keinginan berpindah kerja: Survey pada kantor akuntan publik di wilayah Surakarta. Skripsi yang tidak dipublikasikan, Universitas Muhamadiyah, Surakarta.

Irving, P.G., Coleman, D.F., \& Cooper, C.L. (1997). Further assessment of a three-component model of occupational commitment: Generalizability and differences across occupations. Journal of Applied Psychology, 82 (3), 444-452.

James, L.R., Mulaik, S.A. \& Brett, J.M. (1982). Causal analysis: Assumptions, models, and data. $5^{\text {th }}$ edition, NJ: Prentice-Hall International, Inc.

Kerlinger, F.N. (2002). Asas-asas penelitian behavioral. Yogyakarta: Gajah Mada University Press.

Kossek, E.E., \& C. Ozeki. (1998). Work-family conflict, policies, and the job-life satisfaction relationship: A review and directions for organizational behavior-human resource research. Journal of Applied Psychology 82 (2), 139-149.

Kossen, S. (1986). Aspek manusiawi dalam organisasi. Jakarta: Erlangga.

Kussudyarsana \& Soepatini. (2008). Pengaruh karier objektif pada wanita terhadap konflik keluarga-pekerjaan: Kasus pada Universitas Muhammadiyah Surakarta. Jurnal Penelitian Humaniora, 9 (2), 128-145.

Marwansyah \& Mukaram. (2000). Manajemen sumber daya manusia. Bandung: Pusat Penerbit Administrasi Niaga Politeknik Negri Bandung.

Meyer, J.P., Allen, N.J., \& Smith, C. (1993). Commitment to organizations and occupations: Extension and test of a three-component conseptualization. Journal of Applied Psychology, 78, 538-551.

Namasivayam, K., \& Zhao, X.(2006). An investigation of the moderating effects of organizational commitment on the relationship between work-family conflict and job satisfaction among hospitality employees in India. Tourism Management, doi:10.1016.

Noor, M.N. (2006). Locus of control, supportive workplace policies and work-family conflict. Pyschologia. 49, 48-60.

Panggabean, M. S. (2006). Hubungan diantara keterlibatan kerja, kepuasan kerja, dan komitmen organisasi. Jurnal Manajemen Sumber Daya Manusia dan Organisasi 1 (1), $1-34$.

Pasewark, W. R. \& Ralph E. Viator. (2006). Source of work-family conflict in the accounting profession. Behavioral Research in Accounting, Pg: 147-165.

Riley, D. (2006). Turnover intention: The mediation effects of job satisfaction, affective commitment, and continuance commitment. Unpublished doctoral dissertation, University of Waikato.

Sekaran, U. (2000). Research methods for business: A skill-building approach. $3^{\text {rd }}$ edition, NY: John Wiley \& Sons, Inc. 
Setyawan, A. D. (2008). Pengaruh komitmen organisasi terhadap kepuasan kerja dengan motivasi sebagai variabel intervering: Survey di kantor akuntan publik di karisidenan Surakarta dan Yogyakarta. Skripsi yang tidak dipublikasikan, Universitas Muhamadiyah, Surakarta.

Srimulyani, V. A. (2009). Tipilogi dan anteseden komitmen organisasi. Jurnal IImiah Widya Wana. 33 (1), 1-20.

Sunjoyo. (2008). Model trickle-down keadilan organisasional: Keterkaitan persepsi para dosen dan mahasisiwa serta berbagai reaksi para mahasiswa terhadap keadilan. Laporan riset yang tidak dipublikasikan, Universitas Kristen Maranatha, Bandung.

Tobing, D.S.K.L. (2009). Pengaruh komitmen organisasional dan kepuasan kerja terhadap kinerja karyawan PT. Perkebunan Nusantara III di Sumatera Utara. Jurnal Manajemen dan Kewirausahaan. 11 (1), 31-37.

Triaryati, N. (2003). Pengaruh adaptasi kebijakan mengenai work family issue terhadap absen dan turnover. Jurnal Manajemen dan Kewirausahaan. 5 (1), 85-96.

Turban, D.B. \& Dougherty, T.W. (1994). Role of protégé personality in receipt of mentoring and career success. Academy of Management Journal, 37 (3), 668-720. 


\section{Lampiran: Kuesioner Penelitian}

\begin{tabular}{|c|c|}
\hline No & $\bar{n}$ \\
\hline 1 & $\begin{array}{l}\text { Berbagai tuntutan pekerjaan saya sebagai perawat mengganggu kehidupan } \\
\text { pribadi saya (Rumah, keluarga atau waktu senggang saya). }\end{array}$ \\
\hline 2 & $\begin{array}{l}\text { Berbagai tuntutan waktu dari pekerjaan saya sebagai perawat membuat sulit untuk } \\
\text { hadir dalam rumah, keluarga atau berbagai tanggung jawab pribadi. }\end{array}$ \\
\hline 3 & $\begin{array}{l}\text { al-hal yang ingin saya lakukan di rumah tidak dapat saya lakukan karena berbagai } \\
\text { ntutan pekerjaan saya sebagai perawat. }\end{array}$ \\
\hline 4 & $\begin{array}{l}\text { Pekerjaan saya sebagai perawat membuat stres yang menyulitkan saya untuk } \\
\text { memenuhi berbagai kewajiban pribadi maupun keluarga. }\end{array}$ \\
\hline 5 & $\begin{array}{l}\text { Karena kewajiban yang berkaitan dengan pekerjaan sebagai perawat, saya harus } \\
\text { membuat berbagai perubahan terhadap rencana-rencana saya tentang waktu } \\
\text { pribadi maupun berbagai aktivitas keluarga. }\end{array}$ \\
\hline 6 & $\begin{array}{l}\text { Berbagai atas pekerjaan saya sebagai perawat membuat untuk sulit bersantai saat } \\
\text { di rumah dan bersama teman-teman. }\end{array}$ \\
\hline 7 & $\begin{array}{l}\text { Berbagai tuntutan keluarga atau pasangan saya mengganggu berbagai aktivitas } \\
\text { yang berhubungan dengan pekerjaan saya sebagai perawat. }\end{array}$ \\
\hline 8 & $\begin{array}{l}\text { ngesampingkan berbagai hal yang sedang saya kerjakan di RSUD Dr. } \\
\text { ena berbagai tuntutan waktu saya di rumah. }\end{array}$ \\
\hline 9 & $\begin{array}{l}\text { Saya mengalami masalah dalam menyelesaikan berbagai hal di RSUD Dr. Moewardi } \\
\text { karena berbagai tuntutan dari keluarga atau pasangan saya. }\end{array}$ \\
\hline 10 & $\begin{array}{l}\text { mah tangga saya mengganggu berbagai tanggung jawab saya di } \\
\text { wardi seperti menyelesaikan pekerjaan tepat waktu, menyelesaikan } \\
\text { arian dan kerja lembur sebagai perawat. }\end{array}$ \\
\hline 11 & $\begin{array}{l}\text { Stres yang berkaitan dengan keluarga mengganggu kemampuan s } \\
\text { melakukan berbagai kewajiban yang berkaitan dengan pekerjaan } \\
\text { perawat. }\end{array}$ \\
\hline 12 & $\begin{array}{l}\text { Keluarga dan teman-teman saya menyita waktu yang saya akan gunakan untuk } \\
\text { bekerja. }\end{array}$ \\
\hline 13 & $\begin{array}{l}\text { Saya bertekad untuk memberikan bantuan apa saja yo } \\
\text { yang diharapkan untuk membantu RSUD Dr. Moewardi }\end{array}$ \\
\hline 14 & $\begin{array}{l}\text { osikan RSUD Dr. Moewardi kepada teman-te } \\
\text { si yang hebat untuk bekerja. }\end{array}$ \\
\hline 15 & ki loyalitas (kesetiaan) yang sangat rendah terhadap RSUD Dr. \\
\hline 16 & $\begin{array}{l}\text { Saya akan menerima hampir setiap jenis penugasan supaya saya dapat tetap } \\
\text { bekerja di RSUD Dr. Moewardi. }\end{array}$ \\
\hline 17 & $\begin{array}{l}\text { Saya menemukan bahwa nilai-nilai yang saya yakini dan nilai-nilai yang diyakini oleh } \\
\text { RSUD Dr. Moewardi sangat mirip. }\end{array}$ \\
\hline 18 & $\begin{array}{l}\text { Saya bangga untuk menceritakan kepada orang lain bahwa saya meupakan } \\
\text { bagian dari RSUD Dr. Moewardi. }\end{array}$ \\
\hline 19 & $\begin{array}{l}\text { Saya hanya dapat bekerja dengan baik bagi sebuah organisasi lain selama jenis } \\
\text { pekerjaan yang saya lakukan sama dengan saat ini. ® }\end{array}$ \\
\hline 20 & $\begin{array}{l}\text { RSUD Dr. Moewardi sungguh memberikan inspirasi yang sangat baik bagi saya dalam } \\
\text { mencapai kinerja kerja. }\end{array}$ \\
\hline 21 & $\begin{array}{l}\text { Hanya membutuhkan sedikit perubahan saja dalam kondisi kerja saat ini, yang } \\
\text { dapat menyebabkan saya untuk meninggalkan RSUD Dr. Moewardi. ® }\end{array}$ \\
\hline 22 & $\begin{array}{l}\text { Saya sangat senang bahwa saya memilih RSUD Dr. Moewardi untuk bekerja } \\
\text { daripada semua organisasi lain yang telah saya pertimbangkan pada saat } \\
\text { bergabung dengan RSUD Dr. Moewardi. }\end{array}$ \\
\hline 23 & $\begin{array}{l}\text { Tidak ada banyak hal yang bisa saya dapatkan jika tetap berada di RSUD Dr. } \\
\text { Moewardi untuk jangka waktu yang tidak terbatas. ® }\end{array}$ \\
\hline 24 & Seringkali, saya sulit menerima berbagai kebijakan RSUD Dr. Moewardi atas b \\
\hline
\end{tabular}




\begin{tabular}{|c|c|}
\hline No & Pernyataan \\
\hline 25 & Saya benar-benar peduli terhadap nasib RSUD Dr. Moewardi. \\
\hline 26 & $\begin{array}{l}\text { Bagi saya, RSUD Dr. Moewardi adalah yang terbaik dari semua kemungkinan } \\
\text { berbagai organisasi untuk bekerja. }\end{array}$ \\
\hline 27 & $\begin{array}{l}\text { Memutuskan untuk bekerja di RSUD Dr. Moewardi merupakan sebuah kesalahan fatal } \\
\text { bagi saya. ® }\end{array}$ \\
\hline 28 & Pekerjaan saya sebagai perawat bagaikan suatu hobi bagi saya. \\
\hline 29 & $\begin{array}{l}\text { Pekerjaan saya sebagai perawat biasanya cukup menarik untuk mempertahankan } \\
\text { saya dari kebosanan. }\end{array}$ \\
\hline 30 & Kelihatannya teman-teman saya lebih tertarik dalam pekerjaan-pekerjaannya. \\
\hline 31 & Saya menganggap pekerjaan saya sebagai perawat lebih tidak menyenangkan. ( \\
\hline 32 & Saya menikmati pekerjaan saya sebagai perawat lebih dari waktu senggang saya. \\
\hline 33 & Saya seringkali bosan dengan pekerjaan saya sebagai perawat. ® \\
\hline 34 & Saya merasa cukup puas dengan pekerjaan sebagai perawat saat ini. \\
\hline 35 & Seringkali, saya harus memaksakan diri saya sendiri untuk berangkat bekerja. ( \\
\hline 36 & Saya puas dengan pekerjaan saya sebagai perawat hingga saat ini. \\
\hline 37 & $\begin{array}{l}\text { Saya merasa bahwa pekerjaan saya sebagai perawat tidak lebih menarik daripada } \\
\text { berbagai pekerjaan lain yang bisa saya dapatkan. }{ }^{\circledR}\end{array}$ \\
\hline 38 & Saya sungguh-sungguh tidak menyukai pekerjaan sebagai perawat. ${ }^{\circledR}$ \\
\hline 39 & $\begin{array}{l}\text { Saya merasa bahwa saya lebih bahagia dalam pekerjaan saya sebagai perawat } \\
\text { daripada kebanyakan kebanyakan orang lain. }\end{array}$ \\
\hline 40 & Seringkali, saya antusias terhadap pekerjaan saya sebagai perawat. \\
\hline 41 & Setiap hari kerja tampaknya tidak pernah akan berhasil. ( \\
\hline 42 & $\begin{array}{l}\text { Saya menyukai pekerjaan saya sebagai perawat lebih dari rata-rata yang dilakukan } \\
\text { pekerja. }\end{array}$ \\
\hline 43 & Pekerjaan saya sebagai perawat agak tidak menarik. @ \\
\hline 44 & $\begin{array}{l}\text { Saya menemukan sukacita yang sesungguhnya dalam pekerjaan saya sebagai } \\
\text { perawat. }\end{array}$ \\
\hline 45 & Saya kecewa karena telah menerima pekerjaan ini sebagai perawat. ® \\
\hline
\end{tabular}

\section{Keterangan:}

$\AA=$ Reversed scores; Work interfering with the family (1-6); Family interfering with the work (712); Komitmen organisasional (13-27); Kepuasan kerja (28-45).

1 = Sangat Tidak Setuju, 2 = Tidak Setuju, 3 = Netral, 4 = Setuju, 5 = Sangat Setuju 